\title{
Ecological and cenotic characteristics of communities involving the species of Prunella vulgaris L. and Prunella grandiflora L. in the Middle and Southern Urals
}

\author{
Elizaveta Bolotnik* \\ Russian Academy of Science, Ural Branch: Institute Botanic Garden, 620144, 8 March street, 202a, \\ Yekaterinburg, Russia
}

\begin{abstract}
On the territory of the Middle and Southern Urals, P. vulgaris is found in pine, spruce-pine, birch forests, meadows and in artificial spruce-larch forest plantations; P. grandiflora - in birch forests, less often on meadows. P. vulgaris is confined to half-open places or light-forest with moistening from sub-forest-meadow to wet forest-meadow with not very rich or rather rich soils. $P$. grandiflora grows in semi-open spaces and in light forests with moistening from wet-steppe to dry-forest-meadow with rather poor soils. Both species are found on very poor soils and the ones that are poor in nitrogen, having a weak acidic and acidic soil medium. According to the soil acidity factor, the amplitude of the ecological space of $P$. grandiflora coenopopulations on studied territory goes beyond the ranges of the ecological range according to the scales of D.N. Tsyganov.
\end{abstract}

Prunella vulgaris L. and Prunella grandiflora (L.) Scholler are promising medicinal plants for the production of biologically active substances and creation of medical products. The literature mainly has information on the biology and ecology of $P$. vulgaris [1-3], while the location and phytocenotic data of the closely related species $P$. grandiflora in the natural environment of the Middle and Southern Urals require clarification. The purpose of this work was to identify typical habitats and phytocenotic confinedness of $P$. vulgaris and $P$. grandiflora in the Middle and Southern Urals, to carry out an ecological-cenotic analysis of communities featuring the studied species.

During the expeditionary research in the period from 2011 to 2014 in the Middle and Southern Urals, in various parts of the area, 20 coenopopulation groups of the genus Prunella were studied. The characteristics of the data collection sites of the studied samples are given in Table 1.

The description of the vegetation was carried out in the studied areas at the sites of $10 \times 10 \mathrm{~m}$ [4]. The abundance of species in phytocenoses was indicated as a percentage. In our work, the scales of D.N. Tsyganov [5] were used to assess the following environmental factors in the vegetation habitats of $P$. vulgaris and $P$. grandiflora species: soil moisture

\footnotetext{
${ }^{*}$ Corresponding author: lizavb@yandex.ru
} 
(Hd), soil trophicity $(\mathrm{Tr})$, available nitrogen content in soil $(\mathrm{Nt})$, soil acidity $(\mathrm{Rc})$, and habitat shade $(\mathrm{Lc})$. The assessment of the environmental factor in points was calculated by the generally accepted method [6-7].

Table 1. Characteristics of the data collection sites of the studied samples of $P$. vulgaris and $P$. grandiflora

\begin{tabular}{|c|c|c|}
\hline № & Habitat & Coordinates \\
\hline \multicolumn{3}{|c|}{ P. vulgaris } \\
\hline CP 1 & $\begin{array}{l}\text { Aleksandrovsky sopka, Sverdlovsk region, Krasnoufimsky district, the } \\
\text { southern slope of the hills }\end{array}$ & $\begin{array}{l}\text { N } 56^{\circ} 43^{\prime} 14.8^{\prime \prime} ; \\
\text { E } 057^{\circ} 47^{\prime} 08.5^{\prime \prime}\end{array}$ \\
\hline CP 2 & $\begin{array}{l}\text { Mokraya, Sverdlovsk region, Krasnoufimsky district, to the north of the } \\
\text { Mariisky village - Ust-Mash, the central part of the southeastern slope of } \\
\text { Mokraya mountain }\end{array}$ & $\begin{array}{l}\text { N } 56^{\circ} 19^{\prime} 51 " ; \\
\text { E } 057^{\circ} 53^{\prime} 56.6^{\prime \prime}\end{array}$ \\
\hline CP 3 & $\begin{array}{l}\text { Yenapayevo, Perm region, near the Iren River and the Yanybaevo village, } \\
\text { southeast slope of the mountain }\end{array}$ & $\begin{array}{l}\text { N 563' } 36.5^{\prime \prime} \\
\text { E } 057^{\circ} 55^{\prime} 18.5^{\prime \prime}\end{array}$ \\
\hline CP 4 & $\begin{array}{l}\text { Sverdlovskoye, Sverdlovsk region, southeast of Krasnoufimsky district, } \\
\text { birch forest on the southwestern slope of the mountain, northeast of the } \\
\text { village Sverdlovskoye }\end{array}$ & $\begin{array}{l}\text { N } 56^{\circ} 11^{\prime} 47.8^{\prime \prime} \\
\text { E } 058^{\circ} 22^{\prime} 50.2^{\prime \prime}\end{array}$ \\
\hline CP 5 & $\begin{array}{l}\text { Sredny Munchug, the Republic of Bashkortostan, Mechetlinsky district, } \\
\text { near the Bolsheustikinskoe village, birch forest on the southwestern slope } \\
\text { of Sredny Munchug mountain }\end{array}$ & $\begin{array}{l}\text { N 555ㄴ'38.3"; } \\
\text { E } 058^{\circ} 26^{\prime} 26.5^{\prime \prime}\end{array}$ \\
\hline CP 6 & $\begin{array}{l}\text { Ilek, Chelyabinsk region, Ashinsky district, birch forest near the Ilek } \\
\text { village }\end{array}$ & $\begin{array}{l}\text { N } 55^{\circ} 13^{\prime} 44^{\prime \prime} \\
\text { E } 58^{\circ} 0^{\prime} 5^{\prime \prime}\end{array}$ \\
\hline CP 7 & $\begin{array}{l}\text { Kutushevo, the Republic of Bashkortostan, Mechetlinsky district, south- } \\
\text { eastern slope of a mountain near the Kutushevo village, edge of birch } \\
\text { forest }\end{array}$ & $\begin{array}{l}\text { N } 55^{\circ} 20^{\prime} 56.7^{\prime \prime} \\
\text { E } 058^{\circ} 29^{\prime} 11.1^{\prime \prime}\end{array}$ \\
\hline \multicolumn{3}{|c|}{ P. grandiflora } \\
\hline CP 1 & $\begin{array}{l}\text { Kurgatovo, the Republic of Bashkortostan, Mechetlinsky district, to the } \\
\text { west of the Kurgatovo village, the right bank of the Oka river }\end{array}$ & $\begin{array}{l}\text { N } 56^{\circ} 11^{\prime} 39.8^{\prime \prime} ; \\
\text { E } 058^{\circ} 22^{\prime} 20.2^{\prime \prime}\end{array}$ \\
\hline CP 2 & $\begin{array}{l}\text { Bolshiye Klyuchi, Perm region, the northern slope, near the Bolshiye } \\
\text { Klyuchi village }\end{array}$ & $\begin{array}{l}\text { N } 57^{\circ} 01^{\prime} 05.7^{\prime \prime} \\
\text { E } 057^{\circ} 025^{\prime} 40.1^{\prime \prime}\end{array}$ \\
\hline CP3 & $\begin{array}{l}\text { Ust-Utka (the Chusovaya river), Sverdlovsk region, Nature Park } \\
\text { "Chusovaya River", the Ust-Utka village }\end{array}$ & $\begin{array}{l}\text { N } 57^{\circ} 37^{\prime} 51.1^{\prime \prime} \\
\text { E } 059^{\circ} 03^{\prime} 05.5^{\prime \prime}\end{array}$ \\
\hline CP 4 & $\begin{array}{l}\text { Nizhny Irginsk, Sverdlovsk region, northwestern part of Krasnoufimsky } \\
\text { district, near the Nizhny Irginsk village }\end{array}$ & $\begin{array}{l}\text { N } 56^{\circ} 52^{\prime} 33.1^{\prime \prime} \\
\text { E } 057^{\circ} 27^{\prime} 00.5^{\prime \prime}\end{array}$ \\
\hline CP 5 & $\begin{array}{l}\text { Khrustalnaya, Sverdlovsk region, Pervouralsky district, pine forest near } \\
\text { the station Khrustalnaya }\end{array}$ & $\begin{array}{l}\text { N 565ㅇ'58.6"; } \\
\text { E } 060^{\circ} 10^{\prime} 13.8^{\prime \prime}\end{array}$ \\
\hline CP 6 & $\begin{array}{l}\text { Sysert (the UrFU Biological Station), Sverdlovsk region, Sysert district, } \\
\text { pine forest near the Ural State University biological station }\end{array}$ & $\begin{array}{l}\text { N } 56^{\circ} 36^{\prime} 4 " ; \\
\text { E } 61^{\circ} 32^{\prime \prime} 25^{\prime \prime}\end{array}$ \\
\hline CP 7 & $\begin{array}{l}\text { Orlovka, Chelyabinsk region, Ust-Katavsky district, pine forest near the } \\
\text { village Orlovka, the bank of the Katav River }\end{array}$ & $\begin{array}{l}\text { N } 54^{\circ} 52^{\prime} 17^{\prime \prime} \\
\text { E } 58^{\circ} 5^{\prime} 22^{\prime \prime}\end{array}$ \\
\hline CP 8 & Kiselevo, Perm region, a meadow near the Kiselevo village & $\begin{array}{l}\text { N } 57^{\circ} 07^{\prime} 02.6^{\prime \prime} ; \\
\text { E } 057^{\circ} 20^{\prime} 28.0^{\prime \prime}\end{array}$ \\
\hline CP 9 & $\begin{array}{l}\text { Baikalovo (Shalamy), Sverdlovsk region, Baikalovsky district, birch forest } \\
\text { near the Shalamy village }\end{array}$ & $\begin{array}{l}\text { N } 57^{\circ} 20^{\prime} 50.2^{\prime \prime} \\
\text { E } 063^{\circ} 39^{\prime} 45.6^{\prime \prime}\end{array}$ \\
\hline CP 10 & Guselnikovo, Perm region, a meadow near the Guselnikovo village & $\begin{array}{l}\text { N } 57^{\circ} 19^{\prime} 39.71^{\prime}, \\
\text { E } 57^{\circ} 24^{\prime} 3.65^{\prime},\end{array}$ \\
\hline CP 11 & Severka, Sverdlovsk region, birch forest near the Severka village & $\begin{array}{l}\text { N } 56^{\circ} 52^{\prime} 36.5^{\prime \prime} \\
\text { E } 060^{\circ} 18^{\prime} 41.8^{\prime \prime}\end{array}$ \\
\hline CP 12 & Itkul, Chelyabinsk region, birch forest near the Itkul lake & $\begin{array}{l}\text { N 569'24.59'’; } \\
\text { E 060³4'11.32', }\end{array}$ \\
\hline CP 13 & Altynnoye, Perm region, spruce-larch planting near the & $\begin{array}{l}\text { N } 56^{\circ} 48^{\prime} 25.5^{\prime \prime} \\
\text { E 057 }\end{array}$ \\
\hline
\end{tabular}


Based on 20 descriptions (7 of which with P. grandiflora, 13 with P. vulgaris), 2 dendrograms of the similarity of the communities under review for each of the studied species were constructed.
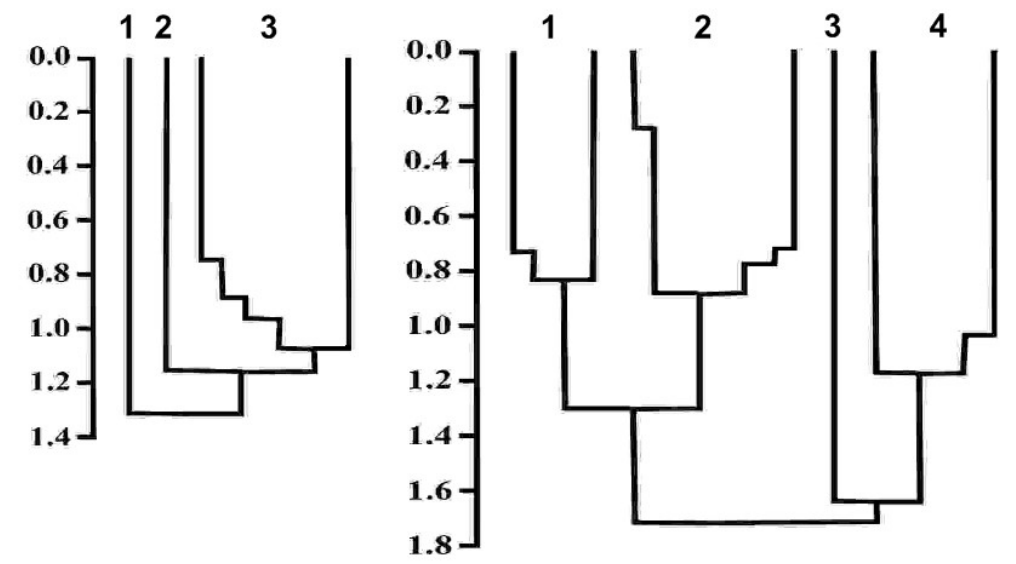

A

B

Fig. 1. A) Similarity dendrogram of community types involving $P$. grandiflora 1-3 - number of clusters (community types) B) Similarity dendrogram of community types involving $P$. vulgaris $1-4-$ number of clusters (community types). Ward's clustering method [8], Sokal / Sneath coefficient No 4 [9].

The dendrogram (Fig. 1A) of communities' types involving P. grandiflora is divided into two branches at a clustering level 1,3. The 1st cluster is represented by the description set in Krasnoufimsky district of the Sverdlovsk region, Mount Mokraya. The community is represented by a forest meadow with single trees Betula pendula. There are 54 species on the area of $100 \mathrm{~m}^{2}$. The herb layer is dominated by: Prunella grandiflora (with an average projective cover of $15 \%$ ), Trifolium medium (10\%), Inula hirta (8\%) and Gentiana cruciata (8\%). Codominants are Fragaria vesca (4\%), Origanum vulgare (3\%), Galium boreale (3\%), Fragaria viridis (3\%), Centaurea scabiosa (3\%), Knautia arvensis (3\%), Amoria montana (3\%) and Galium mollugo (3\%).

At the clustering level of 1,2 , one description (the 2 nd cluster) represented by a closed birch forest, separated from the second branch. The community is described $2 \mathrm{~km}$ northeast of the Sverdlovskoye village, Krasnoufimsky district of Sverdlovsk region, the southwestern slope of the hill (steepness of slope $30^{\circ}$ ). The tree layer is formed by Betula pendula (projective cover of 45\%) with a slight admixture of Populus tremula. Herb layer is well developed (projective cover of 90\%), 60-70 cm high, has 44 species per $100 \mathrm{~m}^{2}$. Herb layer is dominated by Rubus saxatilis $(10 \%)$, Festuca pratensis $(8 \%)$, Calamagrostis epigeios (7\%), Brachypodium pinnatum (7\%). The projective cover of $P$. grandiflora is $3 \%$. The species at this point is located on the border of its range and forms a local shrinking population.

The 3rd cluster combines sparse birch forests (Betula pendula), bordering meadow edge communities. Tree layer projective cover is up to $30 \%$. The height of the main canopy is 12-14 m with trunk diameter of $25-30 \mathrm{~cm}$ with a slight admixture of aspen (Populus tremula). The cenoses range from 44 to 80 species per $100 \mathrm{~m}^{2}$. Herb layer is well developed (projective cover of $80-95 \%$ ), 60-70 $\mathrm{cm}$ high. The herb layer is dominated by Achillea millefolium (with an average coating of 3\%), Calamagrostis epigeios (2\%), Cerasus fruticosa (2\%), Galium verum (3\%), G. boreale (3\%), Filipendula vulgaris (5\%), Inula hirta (2\%), Origanum vulgare (3\%), Prunella grandiflora (9\%), Rubus saxatilis (2\%), Sanguisorba officinalis (2\%), Seseli libanotis (4\%), Stachys officinalis (2\%), 
Polygonatum odoratum (2\%), Vicia cracca (2\%). The projective cover of $P$. grandiflora varies from 4 to $12 \%$. The abundance of $P$. grandiflora in these habitats cannot be called the highest, but the habitats are the most characteristic for this species.

The dendrogram of community types involving P. vulgaris (Fig. 1B) divided into two branches at the clustering level of 1,7. The first branch united birch forests and meadow communities near the birch forests; the second - pine, spruce-pine forests and spruce-larch forest plantation. Each of the two branches was divided into 2 clusters (community types).

The 1 st cluster unites birch forest communities. The tree layer is represented by Betula pubescens with a slight admixture of Populus tremula and Sorbus aucuparia. The projective cover of the tree layer is from 30 to $40 \%, 10-12 \mathrm{~m}$ high, with a trunk diameter of $15-25 \mathrm{~cm}$. The shrub layer is poorly developed and is formed by the Salix caprea. Herb layer is dense $(80-85 \%)$. The dominant is Prunella vulgaris $(7-8 \%)$, codominated by Deschampsia cespitosa (3\%), Festuca pratensis (3\%), Fragaria viridis (3\%), Origanum vulgare (3\%), Phleum pratense (5\%), Pimpinella saxifraga (3\%), Stachys officinalis ( $2 \%$ ), Trifolium medium (4\%), Vaccinium myrtillus (2\%). The relief of the studied area is gently sloping with average heights of 400-500 $\mathrm{m}$ above sea level.

The 2 nd cluster is represented by meadow communities on the edges of birch forests. They are characterized by the inclusion of single trees Betula pendula, Betula pubescens, Sorbus aucuparia and Populus tremula. The cenoses are between 45 and 53 species per 100 $\mathrm{m}^{2}$. Communities are with projective cover of up to $85 \%$ of the grass layer. Prunella vulgaris (7-8\%) dominates, sodominated by Bromopsis inermis (3\%), Dactylis glomerata (4\%), Festuca pratensis (2\%), Filipendula vulgaris (2\%), Fragaria viridis (3\%), Leucanthemum vulgare (3\%), Phleum pratense (5\%), Trifolium medium (3\%).

The 3 rd cluster is represented by the description from Perm region, near the Altynnoye village - spruce-larch forest plantation mixed with Sorbus aucuparia and Padus avium. The tree layer density is $50 \%$. The projective cover of the grass layer is $60 \%$. 41 species have been marked at the area of $100 \mathrm{~m}^{2}$. The herb layer is dominated by Artemisia vulgaris (5\%), Chamaenerion angustifolium (7\%), Dryopteris carthusiana (5\%), Dryopteris filixmas (5\%), Fragaria viridis (5\%). Projective cover of Prunella vulgaris is 5\%.

The 4th cluster combines pine and spruce-pine forests. The cenoses range from 64 to 77 species per $100 \mathrm{~m}^{2}$. The density of the tree layer is from 45 to $50 \%$, the projective cover of the herb layer is from 75 to $90 \%$. Pinus sylvestris (30-50\%), 12-14 m high, with trunk diameter of $15-25 \mathrm{~cm}$, prevails in the tree layer. Picea abies (3-20\%), Betula pendula (1$5 \%$ ) sodominate, Padus avium and Sorbus aucuparia are singled out. Prunella vulgaris (7$12 \%$ ) is dominant in the herb layer; sodominated by Agrostis tenuis (3\%), Calamagrostis arundinacea (5\%), C. epigeios (2\%), Galium boreale (4\%), Geranium sylvaticum (2\%), Rubus saxatilis (4\%), Vaccinium myrtillus (4\%).

In the studied areas $P$. grandiflora is confined to semi-open spaces and light forests (from 2,9 to 3,6 points) with moisture from wet-steppe to dry-forest-meadow (from 9,0 to 10,8 points), it grows on very poor soils and soils poor in nitrogen (from 3,7 to 4,5 points), not rich (from 5,4 to 6,3 points), having acidic and weak acid medium (from 6,0 to 6,7 points) (Table 2.).

Table 2. Comparative ecological characteristics of habitats of $P$. vulgaris, P. grandiflora

\begin{tabular}{|c|c|c|c|}
\hline $\begin{array}{c}\text { Ecological } \\
\text { factors* }\end{array}$ & $\begin{array}{c}\text { Amplitude of the ecological space of } \\
\text { the studied coenopopulations }\end{array}$ & $\begin{array}{c}\text { Points range of } \\
\text { Prunella* }\end{array}$ & $\begin{array}{c}\text { Tsyganov } \\
\text { indicator values* }\end{array}$ \\
\hline \multicolumn{4}{|c|}{$P$. vulgaris } \\
\hline $\mathrm{Hd}$ & $9,9-12,8$ & $7-19$ & $1-23$ \\
\hline $\mathrm{Nt}$ & $4,2-5,1$ & $1-9$ & $1-11$ \\
\hline $\mathrm{Rc}$ & $5,8-6,7$ & $3-11$ & $1-13$ \\
\hline
\end{tabular}




\begin{tabular}{|c|c|c|c|}
\hline Lc & $2,6-4,3$ & $1-6$ & $1-9$ \\
\hline $\mathrm{Tr}$ & $5,4-6,6$ & $1-11$ & $1-19$ \\
\hline \multicolumn{3}{|c|}{ P. grandiflora } \\
\hline $\mathrm{Hd}$ & $9,0-10,8$ & $5-13$ & $1-23$ \\
\hline $\mathrm{Nt}$ & $3,7-4,5$ & $1-7$ & $1-11$ \\
\hline $\mathrm{Rc}$ & $6,0-6,7$ & $7-11$ & $1-13$ \\
\hline $\mathrm{Lc}$ & $2,9-3,6$ & $1-6$ & $1-9$ \\
\hline $\mathrm{Tr}$ & $5,4-6,3$ & $5-7$ & $1-19$ \\
\hline
\end{tabular}

Note: * According to Tsyganov's scale [5]

In the studied phytocenoses, the species $P$. vulgaris is confined to half-open places or light forest (from 2,6 to 4,3) with moistening from sub-forest-meadow to moist-forestmeadow (from 9,9 to 12,8 ), according to the trophic scale grows on poor soils or rather rich ones (from 5,4 to 6,6), very poor and poor in nitrogen (from 4,2 to 5,1), that have an acidic and weak acid medium ( $\mathrm{pH}$ from 5,8 to 6,7).

The data we obtained for $P$. vulgaris and $P$. grandiflora species according to ecological scales allow us to compare with those previously established by D.N. Tsyganov [5] for the European part of Russia and the Urals. It turned out that the species studied within the Middle and Southern Urals are characterized by a relatively narrow range of ecological space according to the considered ecological scales. For most factors, the amplitude of the ecological space of the studied species of the genus Prunella in the territory covered occupies the middle part in the amplitude of the ecological space of the species and does not go beyond the ecological range of species according to the scales of D.N. Tsyganov [5].

In terms of soil conditions, the $P$. vulgaris species reaches its potential to its fullest in relation to soil moistening factor and less in the richness of nitrogen in the soil. $P$. grandiflora for the totality of soil conditions most fully realizes its potential in relation to the factor of soil moistening and less - in acidity. At the same time, according to the acidity of the soil, the species occupies an extreme position - 6-6,7 points (7-11 on D.N. Tsyganov scale) and goes beyond the ranges of the ecological area on the scales of D.N. Tsyganov, which is probably due to the presence of $P$. grandiflora on the northern boundary of the range. $P$. vulgaris in the Middle and Southern Urals grows in habitats from well shaded to poorly lighted ones, on soils with sufficient moisture and nitrogen content. While $P$. grandiflora prefers drier and lighter habitats, with less rich soils and low nitrogen content. On the territory of the Middle and Southern Urals, P. vulgaris is found in pine (Pinus sylvestris), spruce-pine (Pinus sylvestris), birch (Betula pubescens) forests, in meadows and in artificial spruce-larch plantations. P. grandiflora coenopopulations are found in birch forests (Betula pendula), and are less common in meadows, which is probably related to the position of this species on the northeastern boundary of its range.

\section{References}

1. L.I. Abramova, Biological flora of the Moscow region, 12 (1996)

2. I.N. Barsukova, Grow. resources., 3 (2014)

3. E.S. Zakamskaya, Ontogenetic atlas of medical plants, 4 (Yoshkar-Ola, 2004).

4. B.M. Mirkin, Phytocenology: principles and methods (M., Nauka, 1978)

5. D.N. Tsyganov, Phytoindication of ecological regimes in subzone of ConiferousBroadleaved forests (M., Nauka, 1983) 
6. E.V. Zubkova, L.G. Khanina, T.I. Grokhlina, Y.A. Dorogova, Digital processing of geobotanical descriptions using ecological scales and EcoScaleWin Software: manual (Yoshkar-Ola, Mari State University, 2008)

7. P.S.Shirokikh, Agrar. Russia, 1a (2009)

8. J.H. Ward, J. of the Amer. Statistical Association, 58, 301 (1963)

9. R.R. Sokal, P.H.A.Sneath, Principles of numerical taxonomy (San FranciscoLondon, W.H. Freeman and Company, 1963) 